\title{
Factors affecting the performance of triangular pyramid solar still
}

\begin{abstract}
This work presents a few important factors that affect the performance of a triangular pyramid solar still. An experimental work has been conducted to find the effect of water depth on the performance of the triangular pyramid solar still. From the present study, it is concluded that the convective and evaporative heat transfer coefficients are important for designing solar distillation systems and the effect of temperature difference between the evaporative and condensing surfaces is also important to optimize the operating temperature range. The condensing area of the solar still is more than that of evaporating area. Thus the experimental results showed that the effect of depth of water in the solar still affects the fresh water production. Nevertheless, outdoor experimental tests were conducted to study the effect of wind speed variations to cool down the glass cover. It was found that increasing the wind speed from 1.5 to $3 \mathrm{~m} / \mathrm{s}$ and to $4.5 \mathrm{~m} / \mathrm{s}$ has the effect of increasing the still productivity by 8 and $15.5 \%$ respectively.
\end{abstract}

Keyword: Evaporation; Condensation; Water depth; Wind velocity; Parameters 